\title{
PENINGKATAN NILAI PINDANG TONGKOL (Euthynnus affinis) DENGAN PENAMBAHAN VARIAN SAMBAL
}

\author{
A.W., Perdana ${ }^{\mathrm{a}, *}$, B., Kusuma ${ }^{\mathrm{a}}$, A.S.F.Q.R., Mubarok ${ }^{\mathrm{a}}$ \\ ${ }^{a}$ Fakultas Perikanan dan Ilmu Kelautan, Universitas Brawijaya, Jl. Veteran, Malang,Indonesia \\ *Koresponden penulis: anggawirap@ub.ac.id
}

\begin{abstract}
Abtrak
Pindang tongkol merupakan salah satu produk olahan industri perikanan Indonesia. Peningkatan nilai dari pindang tongkol sangat dibutuhkan untuk memperluas pasar. Penambahan sambal yang merupakan kuliner asli Indonesia diharapkan mampu menjadi solusi. Penambahan variasi sambal berdasarkan perbedaan warna yang berbeda ditambahkan pada olahan pindang tongkol menggunakan metode menumis. Hasil uji sensori pasar menunjukkan bahwa varian sambal warna merah paling diterima oleh konsumen, dengan nilai perspektif terhadap warna $81,3 \%$, pespektif terhadap odor $77,6 \%$, perspektif terhadap flavor $76,6 \%$ dan perspektif terhadap tekstur $80,4 \%$.
\end{abstract}

Keywords: Pindang, tongkol, peningkatan, sambal

\begin{abstract}
Abtract
Pindang Tongkol is the processed products of the Indonesian fishery industry. Increasing the value of pindang tongkol is needed to expand the market. The addition of sambal which is an authentic Indonesian culinary is expected to be a solution. The addition of variations of sambal based on color differences is added to the processed pindang tongkol using the stir fry method. The market sensory test results show that the red sambal variant is the most accepted by consumers, with sensory perspective value on color $81,3 \%$, perspective on odor $77,6 \%$, perspective on flavor $76,6 \%$ and perspective on texture $80,4 \%$.
\end{abstract}

Keywords: Pindang, tongkol, enhancement, sambal

\section{PENDAHULUAN}

Pindang merupakan pengolahan ikan secara tradisional dengan peminat yang sangat besar. Proses pemindangan bergantung pada metode penggaraman dan pemanasan dengan tujuan untuk membunuh atau menghambat pertumbuhan bakteri dan kerja enzim. Usaha pemindangan di Indonesia dapat dikatakan berhasil karena kuantitas dari pembelian yang besar. Akan tetapi harga produk pemindangan masih relative rendah. Hal ini merupakan salah satu permasalahan yang dihadapi oleh industry pemindangan [1]. Rendahnya diversifikasi produk olahan pindang dapat dikatakan sebagai salah satu permasalahan terkait dengan industri pemindangan. Rendahnya diversifikasi produk mengakibatkan kurangnya minat HOREKA (hotel, restoran dan kafe) untuk menggunakan pindang sebagai bahan baku pada kuliner yang disajikan [2].
Kuliner dari kawasan asia yang cukup terkenal adalah sambal. Tingkat penerimaan sambal sangat tergantung dari ethnografi masyarakatnya, sehingga menjadi bahan pertimbangan apabila sambal akan dipakai untuk membuat suatu masakan. Tingkat penerimaan penerimaan sebuah kuliner dengan sambal sebagai flavoring agent perlu dilakukan karena sangat krusial terhadap kualitas sensori produk [3]. Indonesia sangat dikenal dengan sambalnya. Berbagai olahan bahan baku tidak lepas dengan keberadaan sambal baik sebagai seasoning maupun flavoring agent. Tiga macam sambal dasar yang sering dipakai oleh masyarakat Indonesia, berdasarkan warna yakni: sambal cabai merah, sambal cabai hijau dan sambal kuning (bumbu kare pedas) $[4,5]$. Penambahan varian sambal pada olahan produk pindang tongkol diharapkan mampu meningkatkan nilai dari pindang tongkol. Olahan pindang tongkol diharapkan mampu bersaing ke 
depannya sebagai menu pada hotel, restoran dan kafe.

\section{METODE}

\section{Preparasi sample}

Pindang tongkol (ukuran tongkol adalah $1 \mathrm{~kg}$ \pm 100 gram) dibeli dari pasar tradisional Dinoyo dan ditransportasikan ke laboratorium menggunakan cool box (es 1:2) dengan kisaran waktu 30 menit. Bahan sambal dibeli di tempat yang sama. Pindang yang telah dibeli untuk selanjutnya dibentuk dengan bentukan fillet dan disimpan sementara di dalam cool box dengan es. Selanjutnya bahan varian sambal (komposisi dapat dilihat pada Tabel 1) ditumis (5\% minyak b/v) pada kisaran suhu $150^{\circ} \mathrm{C} \pm 5$ selama 4 menit \pm 1 . Fillet tongkol dimasukkan dan dimasak pada kisaran suhu yang sama selama 10 menit \pm 1 . Perlakuan varian sambal merupakan modifikasi dari metode Ayu, dkk., 2016 [4] dan Thalib, 2010 [5].

\section{Metode Uji Sensori Pasar}

Uji pasar dilakukan dengan mengujikan secara sensori (penampakan, bau, rasa dan tekstur) kepada panelis. Uji yang dilakukan terhadap panelis menggunakan 7 skala tingkatan penerimaan dengan asumsi data jenis ordinal. Nilai Uji pasar dilakukan dengan modifikasi uji yang dikonsepkan oleh Naes, dkk., 2010 [6].

Tabel 1. Formulasi perlakuan sambal pada pindang tongkol

\begin{tabular}{|c|c|c|c|}
\hline \multirow{2}{*}{ Bahan } & \multicolumn{3}{|c|}{ Komposisi sambal (\%)/kg pindang tongkol } \\
\hline & Merah & Kuning & Hijau \\
\hline Minyak sayur* & 40.52 & 40.52 & 40.52 \\
\hline Bawang merah & 24.31 & 24.31 & 24.31 \\
\hline Tomat & 40.52 & 40.52 & 40.52 \\
\hline Gula pasir & 0.49 & 0.49 & 0.49 \\
\hline Garam & 0.65 & 0.65 & 0.65 \\
\hline Bawang putih & 16.21 & 16.21 & 16.21 \\
\hline Cabe besar merah & 16.21 & 0 & 0 \\
\hline Cabe kecil merah & 1.62 & 0 & 0 \\
\hline Cabe kecil hijau & 0 & 1.62 & 1.62 \\
\hline Cabe besar hijau & 0 & 0.00 & 16.21 \\
\hline Kunyit & 0 & 16.21 & 0.00 \\
\hline
\end{tabular}

\section{Rancangan Penelitian dan Uji Statistik}

Rancangan Acak Lengkap (RAL) digunakan dalam penelitian guna mengetahui efek penambahan sambal terhadap produk varian pindang terhadap parameter uji pasar. Panelis sebagai target uji pasar merupakan mahasiswa Universitas Brawijaya sebanyak 107 orang. Uji statistik ukuran pemusatan data dilakukan menggunakan bantuan software SPSS 16.0 for Windows. Hasil analisis ukuran pemusatan data untuk selanjutnya dilakukan analisis perspektif secara deskriptif.

\section{HASIL DAN PEMBAHASAN}

Hasil penelitian berupa produk dapat diihat pada Gambar 1. Pada gambar disajikan 3 produk dengan dibandingkan antara masing-masing perlakuan dan diberik kode, kemudian dari panelis uji sensori akan memberikan penilaian terhadap produk meliputi warna, odor, flavor dan tekstur.

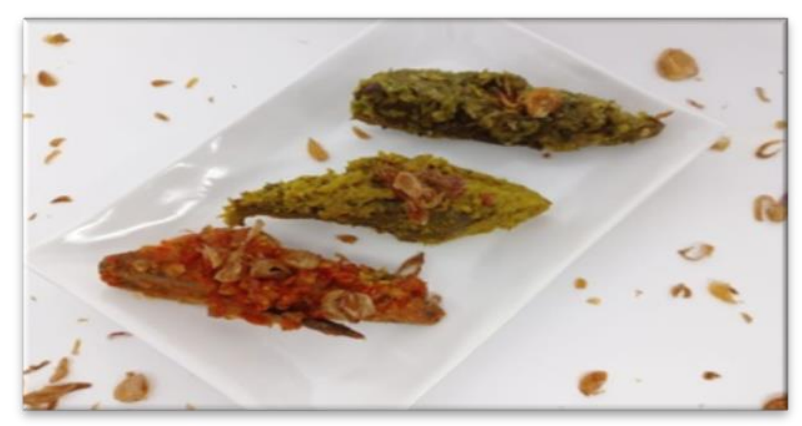

Gambar 1. Pindang Merah (a), Pindang Kuning (b), Pindang Hijau (c) 


\section{Analisis Hasil Uji Sensori Pasar}

Penelitian mengenai uji sensori pasar terhadap olahan pindang tongkol menghasilkan trend positif terhadap penerimaan mahasiswa (dapat dilihat pada grafik 1 sampai dengan 4). Perspektif warna menghasilkan bahwa 81,3\% responden menyukai olahan pindang dengan varian bumbu merah (nilai penerimaan < 4 sebagai batas penolakan). Penilaian terbaik berada pada pindang bumbu merah didasarkan atas frekuensi tertinggi untuk untuk nilai penerimaan warna 6 (44) dan 7 (22). Perspektif odor menghasilkan bahwa $77,6 \%$ responden menyukai olahan pindang dengan varian bumbu merah (nilai penerimaan $<4$ sebagai batas penolakan). Penilaian terbaik berada pada pindang

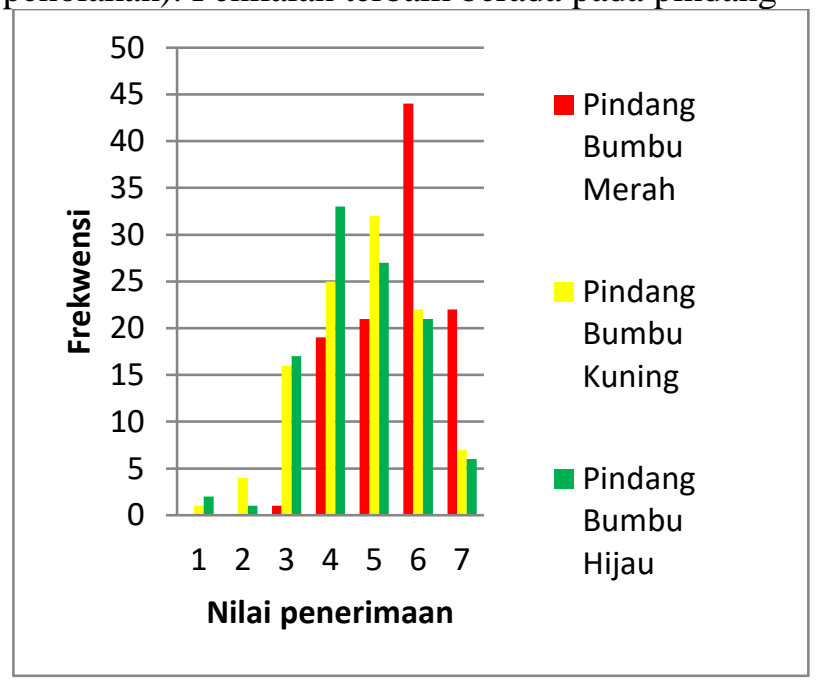

Gambar 1. Grafik uji sensori warna

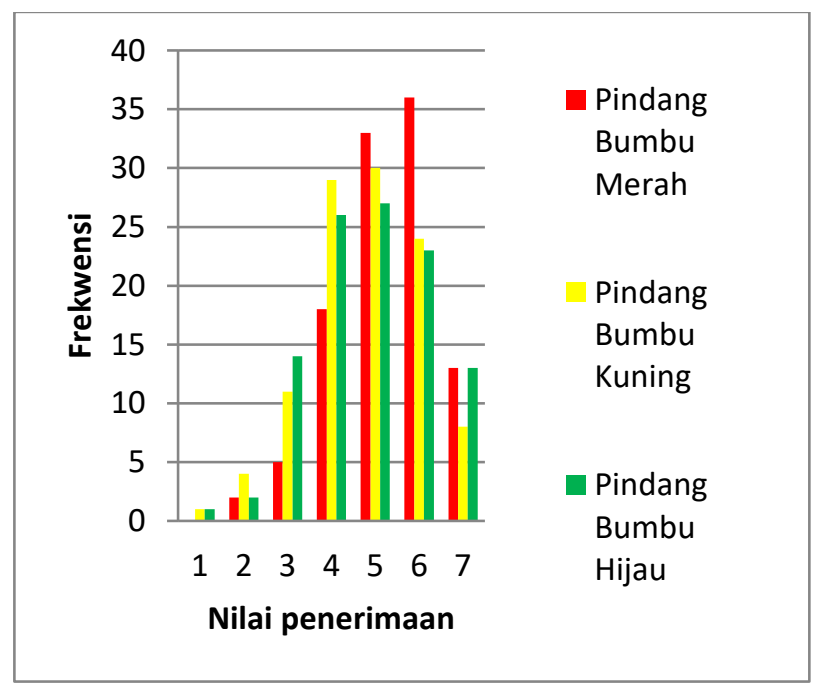

Gambar 3. Grafik uji sensori flavor

Warna sangat berpengaruh terhadap persepsi konsumen. Komponen penyusun warna pada bahan pangan sangat bergantung pada kandungan yang terkandung di dalam bahan pangan tersebut bumbu merah didasarkan atas frekuensi tertinggi untuk untuk nilai penerimaan odor 6 (32) dan 7 (20). Perspektif flavor menghasilkan bahwa 76,6 $\%$ responden menyukai olahan pindang dengan varian bumbu merah (nilai penerimaan $<4$ sebagai batas penolakan). Penilaian terbaik berada pada pindang bumbu merah didasarkan atas frekuensi tertinggi untuk untuk nilai penerimaan flavor 6 (43) dan 7 (23). Perspektif tekstur menghasilkan bahwa $80,4 \%$ responden menyukai olahan pindang dengan varian bumbu merah (nilai penerimaan $<4$ sebagai batas penolakan). Penilaian terbaik berada pada pindang bumbu merah didasarkan atas frekuensi tertinggi untuk untuk nilai penerimaan flavor 6 (36) dan 7 (13).

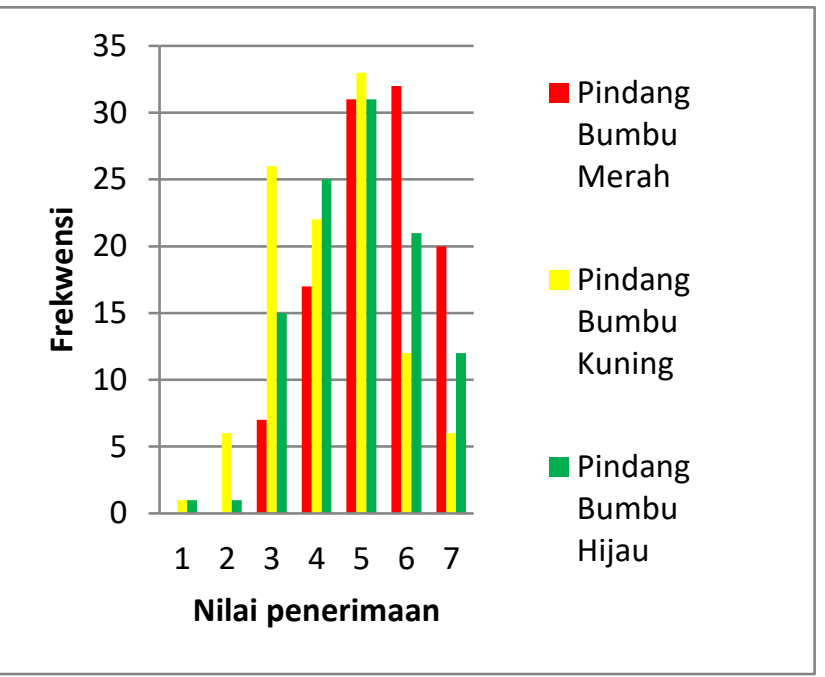

Gambar 2. Grafik uji sensori odor

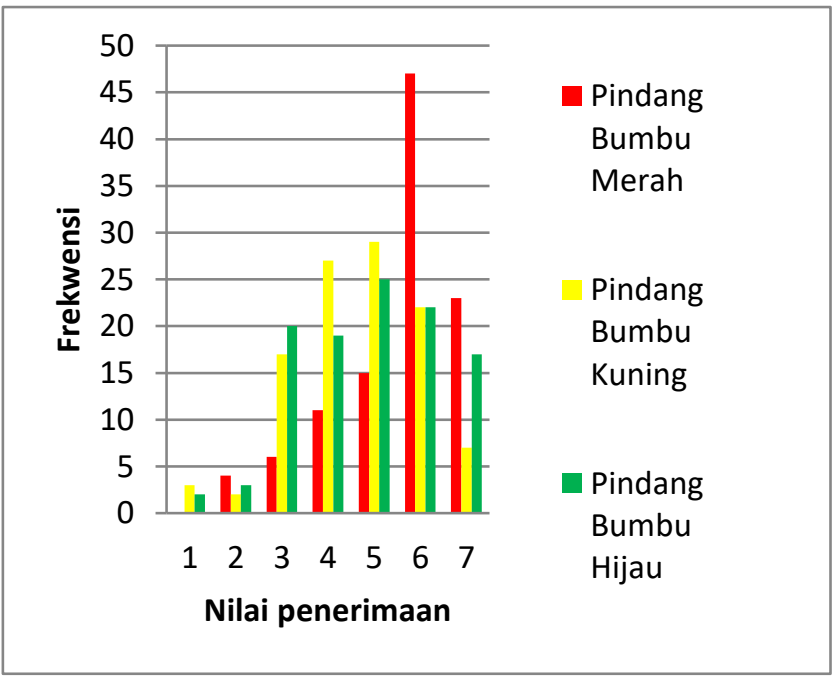

Gambar 4. Grafik uji sensori tekstur

[7]. Faktor lain yang berpengaruh terhadap warna bahan pangan adalah perlakuan proses [8]. Warna merah merupakan salah satu warna yang sangat 
disukai oleh konsumen, khususnya pada bahan pangan [9].

\section{KESIMPULAN}

Penelitian mengenai penerimaan sensori dari olahan pindang dengan perlakuan sambal berbeda menghasilkan bahwa pindang dengan sambal merah lebih diminati dibandingkan dengan produk olahan pindang menggunakan bumbu jenis lainnya.

\section{UCAPAN TERIMAKASIH}

Terimakasih kepada Fakultas Perikanan dan Ilmu Kelautan dalam pemberian dana hibah penelitian bagi dosen, sehingga terlaksananya penelitian ini.

\section{DAFTAR PUSTAKA}

[1] Lumban-B, R.M., Maulina, I., Gumilar, I. 2012. Analisis Pengembangan Usaha Pemindangan Ikan di Kecamatan Bekasi Barat. Jurnal Perikanan dan Kelautan, 3(1): $17-24$.

[2] Hardoko, Sari, P.Y., Puspitasari, Y.E. 2015. Substitusi Jagung Pisang dalam Pembuatan Abon dari Pindang Ikan Tongkol. Jurnal Perikanan dan Kelautan, 20(1): 1-10.

[3] Kim, H.J., Chung, S.J., Kim, K.O., Nielsen, B., Ishii, R., O’Mahony, M. 2018. A Crosscultural Study of Acceptability and and Food Pairing for Hot Sauces. Appetite, DOI: 10.1016/j.appet.2018.01.006.
[4] Ayu, F.W.M., Rosidah, U., Priyanto, G. 2016. Pembuatan Sambal Cabai Hijau Instan dengan Metode Foam Mat Drying. Prosiding Seminar Nasional Lahan Suboptimal, Palembang 20-21 Oktober 2016.

[5] Thalib, A. 2010. Pengaruh Jenis Kemasan terhadap Masa Simpan Bumbu Gulai Pasta. Jurnal Hasil Penelitian Industri, 24(2): 83-87.

[6] Naes, T., Brockhoff, P.B., Tomic, O. 2010. Statistic for Sensori and Customer Service. John Wiley and Sons, Ltd., UK.

[7] Yang, W., Kaimainen, M., Jarvenpaa, E., Sandell, M., Houpalahti, R., Yang, B., Laaksonen, O. 2021. Red beet (Beta vulgaris) betalains and grape (Vitis vinifera) anthocyanins as colorants in white currant juice - Effect of storage on degradation kinetics, color stability and sensori properties. Food Chemistry, 348: 1-10.

[8]. Cervera-Chiner, L., Barrera, C., Betoret, N., Segui, L. 2021. Impact of sugar replacement by non-centrifugal sugar on physicochemical, antioxidant and sensori properties of strawberry and kiwifruit functional jams. Heliyon, 7(1): 1-8.

[9] Aksu, M.I., Erdemir, E., Turan, E., Sat, I.G. 2020. Effects of red beet extracts on protein and lipid oxidation, colour, microbial, sensori properties and storage stability of Turkish pastırma. Journal of Stored Products Research, 89: 1-11. 